\title{
Erratum to: Development of a Short-Form of the RCOPE for Use with Bereaved College Students
}

\author{
Benjamin D. Lord • Elizabeth A. Collison • Sandra E. Gramling • \\ Rachel Weiskittle
}

Published online: 27 September 2014

(C) Springer Science+Business Media New York 2014

\section{Erratum to: J Relig Health DOI 10.1007/s10943-014-9891-6}

In the original publication, the family name of Rachel Weiskittle was misspelled. It is corrected with this erratum.

The online version of the original article can be found under doi:10.1007/s10943-014-9891-6.

B. D. Lord $(\bowtie) \cdot$ E. A. Collison · S. E. Gramling · R. Weiskittle Department of Psychology, Virginia Commonwealth University, 5308 Waverly Avenue, Richmond, VA 23231, USA

e-mail: lordbd@vcu.edu 